\begin{tabular}{lll}
\hline & JSM (10) (1) \\
Jttps://journal.unnes.ac.id/sju/index.php/jsm/index & JURNAL SENI MUSIK
\end{tabular}

\title{
PRESERVATION OF KERONCONG MUSIC THROUGH MUSIC LEARNING AT SMP SANTA ANGELA BANDUNG
}

\section{Hery Supiarza ${ }^{\bowtie}$}

Departement of Music Education, Faculty of Arts and Design Education, Universitas Pendidikan Indonesia.

\section{Muhammad Jausyan Aulia}

Departement of Music Education, Faculty of Arts and Design Education, Universitas Pendidikan Indonesia.

\section{Irwan Sarbeni}

Film and Television Study Program, Faculty of Arts and Design Education, Universitas Pendidikan Indonesia

\begin{tabular}{l} 
Article Info \\
\hline Submitted : May, 202 \\
Revised : May, 202 \\
Accepted : June, 202 \\
\\
\hline Keywords: \\
Music Learning, \\
Keroncong Music, \\
extracurricular, \\
preservation \\
\hline
\end{tabular}

\begin{abstract}
This study discusses the preservation of keroncong music through music learning at Santa Angela Junior High School in Bandung. Keroncong is a type of hybrid music, native to Indonesia, the result of acculturation between Portuguese music and Indonesian local music. Keroncong experiences a setback at the present time, especially among the younger generation. Through teaching and learning activities in schools one way keroncong music can be sustainable and developed. The focus of the problem that was studied included the keroncong music learning material, the learning methods used and the evaluation techniques used from the keroncong music extracurricular activities in Santa Angela Junior High School Bandung.

This research uses a descriptive method with a qualitative approach. Based on research findings, learning keroncong music in extracurricular activities in Santa Angela Junior High School Bandung refers to three main materials namely the skill of playing the keroncong instrument, the skill of playing the keroncong rhythm, the keroncong songs. The benefit of this research is that it can provide innovation in learning keroncong music in schools as an effort to preserve and revitalize one of Indonesia's original music.
\end{abstract}




\section{INTRODUCTIONS}

Keroncong had ever reached its golden age in the early 20th century. At that time, keroncong existed in big cities around Indonesia such as Jakarta, Semarang, Surabaya and Bandung with a variety of styles and innovations. Even in that century, the city of Bandung had many keroncong groups which could be said to be the 'center' of keroncong groups in other cities, including the first women's keroncong orchestra also appeared in Bandung, by the name Bluesterr led by Euis Zuraida (Suadi, 2017). Historically, keroncong music was a type of music that emerged during the arrival of the Portuguese to Indonesia, and the artifact of Portuguese influence on keroncong music is seen especially in the ukulele (a small four-string guitar) which later turned into cuk and cak, pronga and macina, or keroncong and tenor (Supiarza, $\mathrm{H}$. Sobarna, C. Sukmayadi, Y. Mulyadi, 2018). The descendants of the Portuguese can still be found today. They are a large family living in Tugu village located on the coast of Jakarta. Up to now, they still preserve the 'Tugu style' type of keroncong music which was inherited from their elder. It was this invasion of Portuguese culture that made keroncong considered as a type of 'Hybrid music' for it was produced from a combination of Portuguese music and Indonesian music (Ganap, 2000).

Since the 1980s, keroncong music has stagnated, as evidenced by not even a single keroncong music being created (Yampolsky, 2010). The reason was that it was unable to compete with pop music production that dominated the Indonesian music industry (Supiarza, 2019), so since 1980 to present, none of keroncong songs have been created, but just past keroncong songs that are being re-released. Keroncong music is a type of ensemble music that is played together. Keroncong main musical instruments consist of cello, cuk, cak, bass guitar, as well as melodic instruments in the form of flute and violin or one of them. In the context of education, keroncong music can actually be a mean for students to learn a teamwork, and be the most strategic place to preserve original Indonesian music among the youth. One of schools that keeps trying to preserve keroncong music is SMP Santa Angela (Junior High School), Bandung. This effort is considered to be quite interesting because not so many schools are willing to preserve keroncong music in their teaching and learning activities. Through keroncong extracurricular activities, SMP Santa Angela has succeeded in introducing keroncong music to its students. Even through this activity, keroncong group of this extracurricular has proven many achievements. The group's existence also has been recognized in various keroncong music festival activities. Among them are the 2013 Solo Keroncong Festival, the 2013 Keroncong 1000 Song Jamboree, the 2015-2018 Young Keroncong Festival, and various other activities that have made this group known to the wider community.

The theoretical and practical learning process of keroncong music at SMP Santa Angela cannot be separated from the role of the learning method. The learning method used is a very important component in achieving learning objectives. In this study, researchers observed the learning process of keroncong music and managed to get an overview of the methods in used. This method is in the form of lectures, questions and answers, demonstrations, and exercises or drills. Researchers also saw that the teacher approach in this school used teachercentered, where the teacher became the center of learning, especially in determining the media for music training (Iswangga, Muttaqin, \& Wiyoso, 2020). In addition, teachers also take a direct approach to students in practicing patterns of playing musical instruments (Yahya, Fazri Ivan, Haryono, 2020).

The activeness and achievements achieved by SMP Santa Angela in preserving keroncong music, especially in the school environment, are what underlie the researcher to study their learning activities in depth and describe the results comprehensively. Therefore, the research questions are formulated as follows: 1) What material is used in learning keroncong music in extracurricular activities at SMP Santa Angela, City of Bandung?, 2) What methods are used in their learning activities?, and 3) How is the evaluation technique used in their learning activities?.

'Preservation' is a term commonly found in discussions of relics of the past. Efforts to preserve keroncong music have been made by many groups, individuals and government agencies. One manifestation of the effort to preserve keroncong music among the young generation, especially school students, is an activity initiated by the Indonesian Pillar School (SPI), namely a keroncong music competition held annually as a pillar school keroncong festival 
event. The festival has been initiated since 2015 by Windoto Ariwibowo in collaboration with HAMKRI (Rukmana Indra, 2019). The event is deemed to be the only event that accommodates the keroncong festival with special participants from the school circl. This is a concrete example that efforts to preserve keroncong music among the youn generation are still continue today.

Preservation of keroncong music is also carried out in the campus environment. In Bandung itself, the Universitas Pendidikan Indonesia is known as a place for the preservation and development of keroncong music. Through the Music Education Department, young keroncong groups were born which promote keroncong to today's young generation such as O.K. Seven Daughters, O.K. De Oemar Bakrie and O.K. Midaleudami. These keroncong groups are believed to be the carriers of the new keroncong color with the Bandung youth style. This is also acknowledged by keroncong figures from Solo, Jakarta, Semarang and the Indonesian mass media in the form of awards and writings (Supiarza, H. Sobarna, C. Sukmayadi, Y. Mulyadi, 2018). Likewise, with the keroncong orchestra of Santa Angela junior high school students, through teaching and learning activities in keroncong music in the school environment, O.K. Bahana Remaja Bandung, which up to now continues to regenerate well, even supported by students' parents when they participate in activities or organize events (Supiarza, 2019).

To this day, the preservation of keroncong music among Bandung's youth has been able to popularize keroncong music through social media, where it is indeed part of their daily. They create keroncong content and distribute it (Supiarza, 2019). When talking about Bandung's keroncong music in the context of musical popularity and innovation, since 2012 there has been a keroncong innovation among Bandung's young academicians in the form of collaboration that led keroncong music begun to be accepted again, even having the largest number of youth fans in Indonesia. The type of keroncong that combines Jamaican music (ska, reggae) with keroncong then transformed into 'Jamaican Sound Keroncong' with the Sir Iyai music group as a pioneer, making keroncong music accessible to Bandung youths with thousands of fans (Supiarza, H. Sobarna, 2019). The preservation and development of keroncong music for the younger generation must ultimately be in accordance with the way they communicate, participate in life patterns, habits and trends developed in their own world, and keroncong music as a hybrid music is actually eclectic, it can be combined with any types of music.

Music is a work of sound art in the form of a song or musical composition, which expresses the thoughts and feelings of the composer through musical elements including rhythm, melody, harmony, song form or structure, and expression as a whole (Prabowo, Utomo, \& Sinaga, 2020). With music, one can express creativity through sound media which is manifested in various musical elements. Music is a branch of art that discusses and assigns various sounds to patterns that can be understood by humans (Fauble, 2016). Art education that grows and develops in Indonesia can be grouped into two types, school education and out-of-school education. The process can be carried out formally, informally, or informally. Subjects and objects of education can be carried out starting from self (self-education), family, and society, through learning activities, mentoring, and training in the arts.

Learning the art of music is an effort to shape the behaviour of students who are aesthetically pleasing, knowledgeable, possessing attitudes and musical skills both vocals and instruments. These activities can help disseminate the cultural values of the nation, and improve one's attitude and personality, because the art of music is closely related to the sense of beauty and human awareness (Budiwati, 2015: 18). The understanding of the art learning approach has been explained by the PLPG 2013 team (Budiwati, 2015) that learning with art is assumed to be a mean for developing images and creative ideas related to the substance of the object and how to convey it. Learning through art - the foundation of this approach is that art as a learning tool and media that explores and understands the subject matter through various elements of art, while the basis for the 'learning about art' approach is the assumption that art as a learning material demands mastery of the music art materials depicted on musical elements such as rhythm, melody, harmony, form and expression.

In this regard, Harianti (in Budiwati, 2015: 21) reveals the principles of education and learning of arts and culture which include various substances including: (1) expression, including painting, sculpting, arranging waste objects, dancing, singing, music or playing free music according to the rules of art; (2) creation, which includes music creation and song arrangement; (3) skills, which determine technical abilities naturally reproductive, such as singing techniques or playing musical instruments which can allow students to present musical works qualifiedly and aesthetically.

Budiwati (2015) also adds several principles of art learning which can be summarized as follows: 
1. Learning arts in schools must contribute freedom to children to cultivate their creative potential.

2. Learning arts in schools must be able to expand the association and communication of children with their environment.

3. Learning arts in schools should be done in a fun way (joyful learning) and in a free atmosphere without pressure.

Teaching and learning activities can be divided into two categories, intra-curricular and extracurricular learning. Extracurricular is an intra-curricular's supporting activity and takes place outside of academically effective study hours (Iswangga et al., 2020). Extracurricular activities are a form of programmed selfdevelopment activities. These activities are specially planned and followed by students according to their personal needs and conditions.

The scope of its activities is to develop students' knowledge and reasoning abilities, develop skills through their hobbies and interests, and develop attitudes in intra-curricular and cocurricular programs (Suryosubroto, 2002). The existence of extracurricular activities can balance the activities of the intra-curricular program and the co-curricular program because it can help students develop their different potentials. Through the extracurricular program, students can choose activities that match their interests so that students can experience learning outside the classroom.

Based on this explanation, it can be said that music art education in schools is not aimed at producing students to become reliable artists, but is directed at fostering a sense of sensitivity so as to form critical, appreciative, and creative attitudes in students as a whole, as well as providing the ability to express and appreciate art. creatively. Music education can help shape the character of students such as a sense of discipline, tolerance, responsibility, and sensitivity to the environment. This attitude will keep growing if students involve themselves in all artistic activities, both outside and inside the classroom.

As mentioned earlier, that with music, a person can express their creativity through sound media which is manifested in various musical elements including:

1. Melody, the arrangement of a series of tones (sounds with regular vibrations) that sound sequential and rhythmic and contain an idea.

2. Rhythm, the sequence of movements that are the basic elements in music and dance. Rhythm in music is formed from a group of sounds and silence with various lengths of time or length.

3. Tempo, is the fast-slow pace of a song or instrument, or fast-slow motion of the music.
4. Harmony, is the harmony of the chorus which technically includes the composition, role and relationship of the chorus with each other, or the overall form. In other words, harmony is a combination of musical sounds. Harmony is also a branch of music science that discusses the beauty of musical composition (Utomo, U. Sinaga, 2009), (Zalar, Kordes, \& Kafol, 2015).

Therefore, according to these definitions, music can be concluded as a sound that is neatly arranged and becomes a pattern consisting of melody, rhythm, tempo, and harmony.

\section{METHODS}

This study used a descriptive method with a qualitative approach. The descriptive method is used to describe the phenomena that occur in the field learning process of keroncong music in extracurricular program. The phenomenon studied was focused on the keroncong music learning method, the learning stages, and the results obtained from learning keroncong music in extracurricular activities at SMP Santa Angela Bandung. After that, the author conducted research and then described, analysed the findings, and made decision in writing. According to Sugiyono (2016) qualitative researchers as human instruments, functioned to determine the focus of research, select informants as data sources, collect data, interpret data and make conclusions on their findings.

\section{RESULTS AND DISCUSSION}

Each school has its own intra-curricular and extracurricular activities. Intra-curricular activities are the main activities in schools that are binding and consist of various subjects that must be mastered by students as achievements in the academic field. On the other hand, extracurricular activities are non-binding. The participation of students in this activity depends more on the talents, interests, and needs of the students themselves. In other words, extracurricular activities are supporting activities to achieve the intra-curricular activity program.

SMP Santa Angela has several extracurricular activities that are incorporated in various fields, including: 1) Art: Modern dance, Bands, Keroncong, Choirs, Nusantara Dance. 2) Sports: Basketball, Badminton, Voley, Table Tennis Futsal, Taekwondo and Chess. 3) Skills: Graphic design, Culinary, Figuregraphy, STEAM.

The year 2006-2007 was the initial formation of extracurricular music at Santa Angela Junior High School found by Benediktus Sugiyo. He is a teacher of Indonesian Language 
subjects. There are several music genre groups in the extracurricular including Bossa Nova, Country, Pop, and Keroncong.

According to Sugiyo's, for 2 years running, it turns out that keroncong music groups appear to be more prominent than other music groups. In 2008, SMP Santa Angela, as a representative from Bandung, participated in a national level keroncong competition organized by the Santa Maria School Surabaya and immediately won 1st place. After returning from Surabaya, most students started to love keroncong more and led the priority of development more on keroncong music group. Meanwhile, the other music group was coached by new comer music teachers of SMP Santa Angela (on interview, 9 January 2020).

Currently, there are 5 active students consisting of 2 class VII students and 3 class VIII students. Like other extracurricular activities, the problem faced in the even semester is that the number of students will decrease for class IX is no longer allowed to take extracurricular activities to make them focus more on school exams (interview, 9 January 2020).

Based on researcher's observation, keroncong learning activities at SMP Santa Angela have made a major contribution to schools in national scale keroncong music activities, including being a participant in the Solo Keroncong Festival, an international keroncong event in Solo (Supiarza, H. Sobarna, C. Sukmayadi, Y. Mulyadi, 2018).

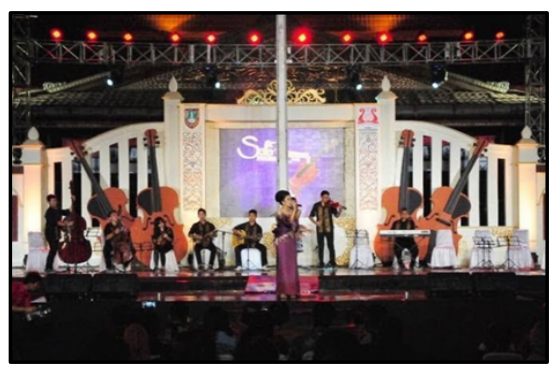

Figure 1. Participanted in Solo Keroncong Festival 2013

The figure 1 above shows one of the roles of the Keroncong Orchestra at SMP Santa Angela in showing the results of learning keroncong music in extracurricular learning. Based on the image documentation above, the researcher argues that the minority of the keroncong movement in Indonesia in the form of performance requires the younger generation to contribute greatly to the preservation of keroncong music. Besides being able to appear more attractive in performances, their participation also provides an injection of energy for the elderly to be more enthusiastic about fighting for keroncong music in the form of providing knowledge to the younger generation.

\section{Keroncong Learning Materials}

Keroncong music learning materials are adapted to the abilities of students participating in keroncong extracurricular activities. Not all students have an understanding or experience of keroncong music. The participation of the keroncong extracurricular activities at SMP Santa Angela for activities inside and outside the school is oriented towards appreciating the quality of keroncong music for junior high school students. The participation of these students in various events shows the existence of the extracurricular itself.

Thus, the trainer must be observant in choosing the material so that the keroncong learning process which only takes place once a week can be organized effectively. If there is an event, usually the school gives permission for additional training for keroncong extracurricular activities. The main material taught by the trainer is the skills to play keroncong instruments, the skills to play keroncong rhythms, and to play songs.

Based on the observations, students' skills in playing keroncong instruments resulted from the learning process of the tool. As stated by Kelvin Kristian (interview, 9 January 2020), the main objective of learning the skills of playing keroncong instruments is to make them able to play keroncong instruments properly and correctly. By mastering the correct playing techniques, players will be able to produce a balanced play for this is an ensemble play (playing different musical instruments together). The process in learning the keroncong musical instrument is as follows:

\section{1) Cuk learning process}

In the initial stage, students received an explanation from the trainer about the parts of the cuk instrument with the lecture method and the position of playing the cuk with the demonstration method. The position of playing the cuk instrument is almost the same as the position of playing the guitar, only the difference is the small size of the cuk. The body position when playing the cuk is in a sitting position. Here are the positions for playing cuk instruments: 


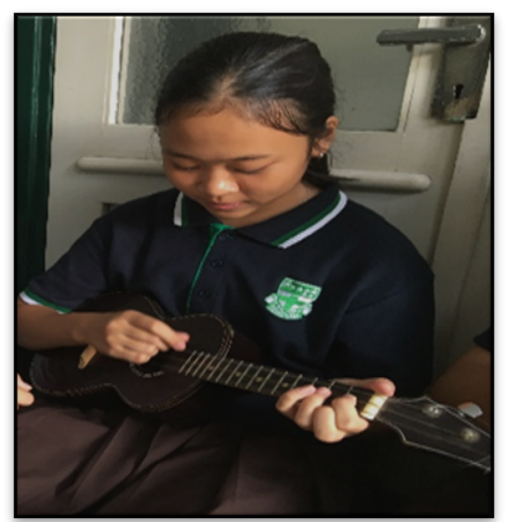

Figure 2. Position of Playing Cuk

Figure above shows the position of holding the cuk as instructed by the trainer. The holding position while sitting can make it easier for students to play the cuk. In a sitting position, the cuk tool can be leaned between the thigh and stomach, so that students can control the movement of the left hand which is tasked to press the strings in $\mathrm{D}$ major chord, and the right hand functioned to sound the strings/ rythem with the Rasgueado technique so as to produce sounds/ tones correctly, according to Kelvin (interview, 9 January 2020).

By the demonstration method, students were also taught how to tune the cuk instrument and how to play it. The notes of the three cuk strings are $G, B, E$. Cuk is played with the rasgueado technique on the down beat beat. The following is the chord progression demonstrated by the teacher with the Rasgueado technique on the down beat beat:

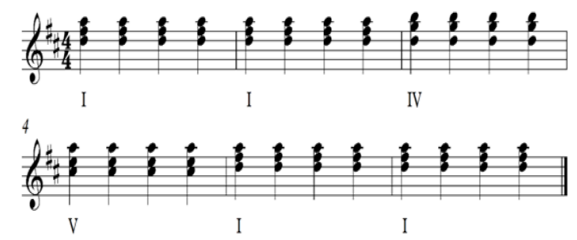

Figure 3. Chord progressions cuk, demonstration of the Rasgueado Technique

The notation figure above is an image of chord progressions I - IV - V - I on the D major scale, the chords are used according to the song played, Bengawan Solo. This song is used as material for practice because it is considered quite simple and popular among students. (interview, 9 January 2020).

\section{2) Cak Learning Process}

After the introduction of the cuk instrument, the trainer then used the lecture method to explain about the cak instrument and explains its anatomy, then the trainer demonstrated how to play it. The position to play it is exactly the same as the position of playing the cuk as follows:

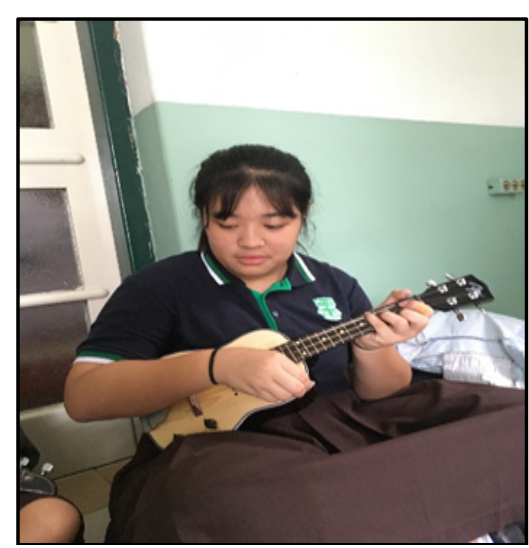

Figure 4. Position of Play Cak

By this position (figure 4), students can control the movement of the left hand which functions to press the strings on D major chord, and the right hand functioned to sound the strings with the staccato technique so as to produce the correct tone, said by Kelvin (interview, 9 January 2020).

The trainer also taught them how to tune the string consisting of 4 strings. The notes of the four cak strings are D, D, Fis, B. After being taught to tune the cak, the trainer then taught the students through demonstrations how to play them. The way to play cak is by using the staccato technique on the beat up beat. Here are the chord progressions:

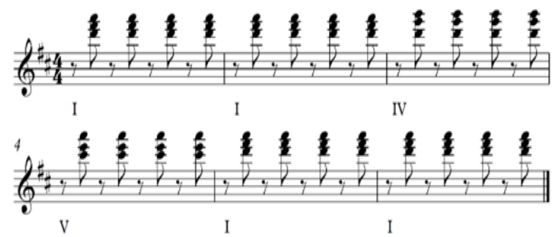

Figure 5. Cak chord progression demonstrated by a trainer with the staccato technique

The notation figure above is an image of I - IV - V - I chord progressions on the D major scale, the chords were used according to the song played in the demonstration which also used the Bengawan Solo song.

\section{3) Learning Cello}

After the introduction of the cak instrument, the coach then used the lecture method to provide an explanation of the cello instrument and explained the parts of the cello and the position of playing the cello with the demonstration method. Here are the positions for playing the cello: 


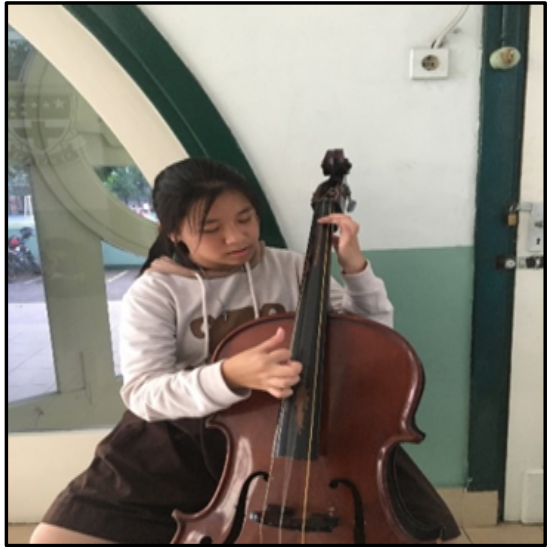

Figure 6. Playing Position of the Cello

Figure 6 shows the position of holding the cello based on the direction of the coach where the cello is positioned to stand between the two legs of the player who is sitting on a chair. This method is considered to ease students to play the cello because the cello has a fairly large and heavy posture for a class of junior high school students. For the left hand position, it functions to press the part of the strings that appears in the picture, namely the A Major chord shape, while the left hand functions to pluck the middle part of the cello to produce a sound. With this position, students can control hand movements to get or produce the correct tone as said by Kelvin (interview, 16 January 2020).

In the learning process, students were also taught how to tune the cello instrument which consists of 3 strings in a row giving $D, G, D$. The following is the cello chord progression demonstrated by the teacher:

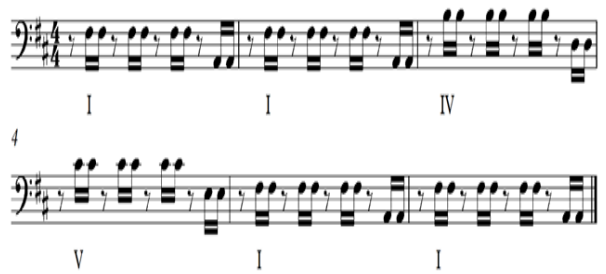

Figure 7.Cello chord progressions the trainer demonstrates

The notation image above is an image of chord progressions I - IV - V - I on the D major scale, the chords are used according to the song played, namely the Bengawan Solo song. This song is used as material for practice based on the results of interviews with researchers because the song Bengawan Solo is considered simple and popular among students. (interview, 16 January 2020).

\section{4) 'Bass Betot' Learning}

After the introduction of the cello instrument, the coach then explained about the bass instrument with the lecture method and demonstrated how to play it. The bass used in keroncong is usually called the bass betot. The position of playing the bass betot is in a standing body position, then the left hand functions to press the strings on the chords and the right hand functions to pick the string as illustrated in the following Figure:

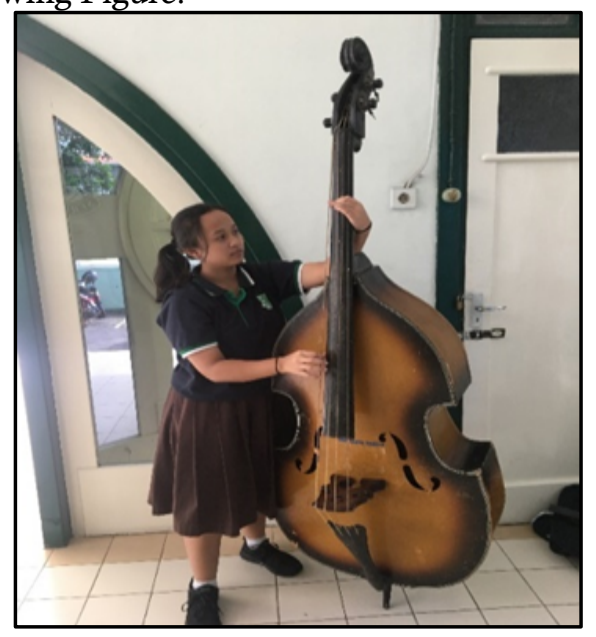

Figure 8. Playing Position of Betot Bass

Figure 8 shows the position of holding the bass betot. This position is considered to ease students to play the bass. The position is related to the fingerings and visually the tone board/ fingerboard can be seen by the player. With this position, students can control hand movements to get the correct tone according to Kelvin (interview, 16 January 2020).

Students were also taught how to tune the bass which has 3 strings. The notes of the three strings are A, D, G. Here are the bass chord progressions the trainer demonstrated:

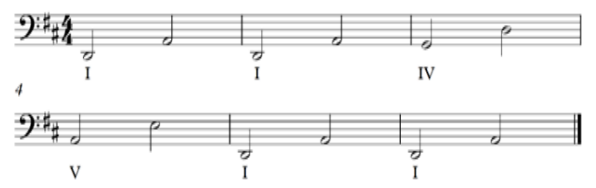

Figure 9. Chord progressions the trainer demonstrates

The notation above is a picture of chord progressions I - IV - V - I on the D major scale, this chord is used according to the song being played, Bengawan Solo (figure 9). This song is still used as material for based exercises because the song is considered simple and popular among students. (interview, 16 January 2020).

\section{Learning Evaluation}

The aim of the evaluation by the trainer is to prepare the keroncong extracurricular participants to be ready to perform well in coming art performances and competitions. By this way the trainer can find out how far the 
students' learning outcomes are, and also to find out the weaknesses and shortcomings of students in playing musical instruments or mastering songs. In addition, evaluation is also needed to determine the success of the trainer in teaching.

In this activity, the keroncong extracurricular trainer at SMP Santa Angela provides an evaluation of the theoretical and practical material that has been taught during music band practice which includes:

1. Play technique

In play technique, the trainer evaluates or assesses students individually or in groups of the way students play a musical instrument.

2. Song material

The trainer sees students in terms of mastery and presentation of song material as a whole and individually. If students feel that they are still lacking in mastering the song material being played, the trainer directs and justifies it so that students can better master and understand the song material being played.

3. Appearance

The trainer also assesses the students' performance in terms of stage mastery, cohesiveness, and communication between players. Based on the results of interviews conducted with Kelvin Kristian as the keroncong extracurricular trainer at Santa Angela Junior High School, to develop the students' abilities in playing keroncong the trainer involved students in several competitions as well as various school activities, such as performing arts.

\section{CONCLUSIONS}

Based on the research results, it can be concluded that the preservation of keroncong music as one of the wealth of Indonesian music can be done through the world of education. Through extracurricular activities at SMP Santa Angela, Bandung City, keroncong music is being reintroduced to the younger generation of Indonesia in practice, so that they know and can feel one type of Indonesian music that must be nurtured and proud of.

Learning Keroncong Music in Extracurricular Activities at SMP Santa Angela Bandung which includes materials, methods, and evaluation techniques are as follows: Keroncong learning material is divided into 3 stages, namely: skills to play keroncong instruments, skills to play keroncong rhythms, and skills to play songs. keroncong song. Learning keroncong in extracurricular activities at SMP Santa Angela Bandung uses learning methods, including: 1) Lecture method by delivering material about keroncong instruments and their parts and describing the types of keroncong music. 2) Demonstration method, the delivery of material in the form of practice such as how to tune and how to play each instrument in keroncong music, then the delivery of material on basic keroncong rhythms, engkel, double, and keroncong songs. 3) The practice/ drill method, which is the delivery of material regarding the skills to play a keroncong instrument, the skills to play keroncong rhythms, and to play keroncong songs. Meanwhile, the learning evaluation technique is to provide an evaluation in the form of theory and practice that has been learned while participating in keroncong extracurricular activities that focus on students' abilities in mastering play techniques, song material, and performances.

\section{REFERENCES}

Budiwati, D. . (2015). Belajar dan Pembelajaran Seni Musik. Bandung: CV. Bintang

Warli.

Fauble, L. (2016). Medicinal Music: An Anatomy of Music in the Healing Arts. Retrieved from http://libproxy.unl.edu/login?url=https: //search.proquest.com/docview/180561 0961 ?accountid=8116\%0Ahttp://library. unl.edu:4550/resserv?genre $=$ dissertation $\mathrm{s}+\% 26+$ theses\&issn $=\&$ title $=$ Medicinal + Music\%3A+An+Anatomy+of+Music+i $\mathrm{n}+$ the + Healing + Arts \&volume $=\&$ issue $=$ \&date $=2$

Ganap, V. (2000). Tugu keroncong music: hybrid genre of Portuguese sojourn. Jurnal Pengetahuan Dan Penciptaan Seni Seni, 2(4), 213-228.

Iswangga, K. D., Muttaqin, M. M., \& Wiyoso, J. (2020). Strategi Pembelajaran Ekstrakurikuler Karawitan Di SMA Negeri 1 Pemalang. Jurnal Seni Musik, 9(2), 109-118. https://doi.org/10.15294/jsm.v9i2.3746 3

Prabowo, A., Utomo, U., \& Sinaga, S. S. (2020). Komposisi Musik Ilustrasi Pada Kelompok Teater Kembang SMA N 1 BREBES. Jurnal Seni Musik, 9(2), 99108. https://doi.org/10.15294/jsm.v9i2.3960 8

Rukmana Indra, A. A. (2019). Musik Keroncong 


\section{Hery Supiarza/JURNAL SENI MUSIK (10) (1)}

Sebagai Media Penanaman Sikap Anti Korupsi (Studi Kasus Pada Festival Musik Keroncong "Jangan Korupsi" di Bogor) Indra. Jurnal Warna, 3(2), 10-21.

Suadi, H. (2017). Djiwa Manis Indoeng Disajang, Musik Dan Dunia Hiburan Tempo Dulu. Bandung: PT. Kiblat Buku Utama.

Sugiyono. (2016). Memahami Penelitian Kualitatif. Bandung: Alfabeta.

Supiarza, H. Sobarna, C. Sukmayadi, Y . Mulyadi, R. (2018). The Prospect and Future of Youth Kroncong Group at Universitas Pendidikan Indonesia in Bandung. Harmonia: Journal of Arts Research and Education, 18(1), 100-110. https://doi.org/10.15294/harmonia.v18i1 .15524

Supiarza, H. Sobarna, C. (2019). "Jamaican Sound Keroncong" Cultural Intermixture Product in the Global Era: A Communication Study on the Spread of Keroncong in the Young Generation of Bandung. Humaniora, 10(1).

Supiarza, H. (2019). Rekonstruksi Musik Keroncong Anak Muda di Kota Bandung. Universitas Padjadjaran.
Suryosubroto. (2002). Proses Belajar Mengajar di Sekolah. Rineka Cipta.

Utomo, U. Sinaga, S. S. (2009). Pengembangan Materi Pembelajaran Seni Musik Berbasis Seni Budaya Berkonteks Kreatif, Kecakapan Hidup, Dan Menyenangkan Bagi Siswa Sd/Mi. Harmonia - Journal of Arts Research and Education, 9(2), 1-13. https://doi.org/10.15294/harmonia.v9i2. 638

Yahya, Fazri Ivan, Haryono, A. (2020). Strategy of Angklung Extracurricular Learning in SMP 13 Cirebon. Jurnal Seni Musik, 9(1), $76-82$.

Yampolsky, P. B. (2010). Kroncong Revisited: New Evidence from Old Sources. Archipel, 79(1), 7-56. https://doi.org/10.3406/arch.2010.4159

Zalar, K., Kordes, U., \& Kafol, B. S. (2015). The Role of Children's Musical Instruments in Communication with Musical Language. Procedia - Social and Behavioral Sciences, 197(February), 1326-1334. https://doi.org/10.1016/j.sbspro.2015.07. 407 